Collection: COST Action FP0905

"Biosafety of forest transgenic trees and EU policy directives"

Guest Editors: Cristina Vettori, Matthias Fladung

\section{Early flowering and genetic containment studies in transgenic poplar}

\author{
Hans Hoenicka, Denise Lehnhardt, Olaf Polak, Matthias Fladung
}

Despite of the immense potential of gene technologies for tree breeding, release of genetic modified trees is still very rare. Biosafety concerns have hitherto limited application of gene technologies. The potential risks of transgenic trees, in particular transfer of recombinant DNA into the gene pool of a given species via vertical gene transfer, have been motive of concern. Biosafety research may allow avoiding potential risks of this technology. However, the evaluation of strategies for prevention of vertical gene transfer, probably the most important concern toward transgenic trees, has been hindered by the long time they require to reach the reproductive phase. We tested different strategies for promoting early flowering in poplar, aiming the development of a system for biosafety studies on gene containment. Early flowering poplar containing the $35 \mathrm{~S}:: L F Y$ or HSP::FT gene constructs allowed first approaches for the faster evaluation of gene containment. However, some drawbacks, e.g., disturbed vegetative growth and flower development, still limit their potential application on biosafety research. A non-transgenic hybrid aspen showing a short vegetative phase was successfully used for the evaluation of the PrMALE1::STS sterility gene construct.

\section{Keywords: Tree breeding, Biosafety, Gene Technology, Hybrid aspen}

\section{Introduction}

The promising prospects offered by gene technologies, especially for tree breeding, have promoted their use in the forestry. An increasing demand of renewable resources has been predicted to meet the energy needs of a growing world population. In the range of different options of renewable resources, woody biomass plays an important role mainly originating from forests including primary or wild forests. Forest plantations with improved genotypes might represent a solution for the increasing pressure on wild forest ecosystems. However, ecological

$\square$ Johann Heinrich von Thünen-Institut (vTI), Intitute of Forest Genetics, Sieker Landstr. 2, D-22927 Großhansdorf (Germany)

@ Matthias Fladung

(matthias.fladung@vti.bund.de)

Received: Jan 24, 2012 - Accepted: May 23, 2012

Citation: Hoenicka H, Lehnhardt D, Polak O, Fladung M, 2012. Early flowering and genetic containment studies in transgenic poplar. iForest 5: 138-146 [online 2012-0613] URL: http://www.sisef.it/

iforest/contents?id=ifor0621-005 boundaries between wild forests and plantations can represent a threat to their integrity. Gene flow from non-native forest trees and taxa resulting from traditional breeding has been motive of concerns in the past (Hoenicka \& Fladung 2006). These concerns have increased since private companies and research institutes worldwide show interest on incorporating genetic engineering into forest tree breeding programs. Release of transgenic trees harbouring particular genes into forest ecosystems would in fact represent an additional risk factor to natural ecosystems.

Until now, strategies for gene flow avoidance between non-native trees taxa derived from traditional breeding have been limited to geographic separation of sexual compatible species. The development of "gene containment" methods using genetic engineering is a promising solution for a more efficiently avoidance of undesired gene flow, not only from genetic modified trees (GM). The incorporation of sterility genes into transgenic lines of trees was proposed to reduce or even avoid gene flow of transgenes into non-transgenic relatives (Strauss et al. 1995). An additional advantage of sterile trees would be the reduction of energetic costs necessary for development of reproductive structures (Brunner et al. 1998, Mouradov et al. 1998).

Various sterility gene constructs have been tested with different levels of success in crop plants, e.g., by expression of deleterious genes in flower organs, like barnase (Paddon \& Hartley 1986, Mariani et al. 1990, GarcíaSogo et al. 2010), orfH522 (Nizampatnam et al. 2009), monooxygenase (MNX - Gan et al. 2010), stilbene synthase (STS - Fisher et al. 1997, Höfig et al. 2006), the gene for ribosome inactivating protein (Palmiter et al. 1987) and RNA interference (Nawaz-ul-Rehman et al. 2007). Specific floral regulatory promoters to direct expression of genes in reproductive structures have been found in crop plants, e.g., TA29 promoter from Nicotiana tabacum (Koltunow et al. 1990, Mariani et al. 1990) and forest tree species, e.g., PrMALE1 from Pinus radiata (Höfig et al. 2003) and PTD from poplar (Skinner et al. 2003).

The number of publications on sterility induction in forest trees is still very low (Meilan et al. 2001, Skinner et al. 2003, Fladung \& Hoenicka 2004, Lemmetyinen et al. 2004, Hoenicka et al. 2006, Wei et al. 2006). Most sterility approaches reported until now were based on gene constructs used successfully in crop plants. Heterologous floral specific promoters can direct activity of cytotoxic gene expression in non-target, vegetative tissues ("leaky" expression) generating in some cases a lower performance of transgenic plants (Lemmetyinen et al. 2004, Meilan et al. 2001, Skinner et al. 2003). Use of floral specific promoters from forest trees have been proposed to overcome such handicaps (Skinner et al. 2003).

The main factor hindering biosafety research on forest trees is the prolonged vegetative phase. This phase is quite variable lasting in some tree species until 40 years (e.g., Fagus sylvatica L. - Meilan 1997). Therefore early flowering trees, either natural or transgenic ones, are very important tools for biosafety research. Most genes involved in the regulation of flowering have been discovered in Arabidopsis (reviewed in Liu et al. 2009). However, flowering time genes have also been studied in woody plants like birch (Elo et al. 2001, 2007), poplar (Rottmann et al. 2000, Böhlenius et al. 2006, Hsu et al. 2006) and apple (Wada et al. 2002).

Several heterologous approaches with flowering time genes have allowed induction of early flowering in perennials. The overexpression of BPMADS4 induce early flowering in birch (Betula pendula - Elo et al.
List of Abbreviations
- GM: genetic modified
- FT: flowering locus T
- HSP: heat shock promoter
- LFY: Leafy
- STS: Stilbene synthase
- UBQII: Ubiquitin II 


\begin{tabular}{|c|c|c|c|c|c|c|}
\hline $35 \mathrm{~S}-\mathrm{P}$ & $L F Y$ & nos- $\mathrm{T}$ & mas $-\mathrm{T}$ & nptl/ & mas- $P$ & LB \\
\hline \multicolumn{7}{|c|}{$35 S:: L F Y$} \\
\hline 35S-T & $F T$ & hsp-P & nos-T & nptll & nos-P & LB \\
\hline \multicolumn{7}{|c|}{ HSP $:: F T$} \\
\hline ocs-T & $L F Y$ & hsp-P & 35S-T & hpt & $35 \mathrm{~S}-\mathrm{P}$ & LB \\
\hline \multicolumn{7}{|c|}{$\mathrm{HSP}:: L F Y$} \\
\hline nos $-P$ & nptll & nos- $T$ & PrMALE1 & STS & nos- $-T$ & LB \\
\hline
\end{tabular}

Fig. 1 - Gene constructs used for genetic transformation.

2007) and apple (Malus $\times$ domestica Borkh - Flachowsky et al. 2007), but not in poplar (Hoenicka et al. 2008). BpMADS4 transgenic lines are currently being used for apple breeding (Flachowsky et al. 2011). The apple gene $M d F T 2$, homologous of $F T$ gene, promoted early flowering in apple and poplar (Tränkner et al. 2010). Arabidopsis flowering time genes Leafy (Schultz \& Haughn 1991) and Flowering locus T (Blázquez \& Weigel 1999) allow the hitherto most efficient early flowering induction in poplar (Weigel \& Nilsson 1995, Rottmann et al. 2000, Zhang et al. 2010). Furthermore, it has been shown that transgenes can induce early flowering in trees more efficiently than cisgenes (Rottmann et al. 2000, Zhang et al. 2010, Flachowsky et al. 2011, Tränkner et al. 2010). Possibly, transgenes are less prone to "endogenous repressors" than cisgenes (Rottmann et al. 2000).

In this study, we evaluated different early flowering systems in poplar aiming their use on biosafety studies on gene containment. We confirmed induction of sterility with the gene construct PrMALE1::STS in the nontransgenic hybrid aspen clone T89.

\section{Material and methods}

Plant material, culture and genetic transformation

In vitro cultures of male hybrid aspen (Populus tremula L. x $P$. tremuloides Michx., clone T89) and Populus tremula L., clone W52 were used for generation of transgenic lines. Plants were grown on solid McCown Woody Plant Medium (WPM, Duchefa M0220 - Lloyd \& McCown 1980) containing 2\% Sacharose, $0.6 \%$ Agar (Agar Agar, Serva, 11396). Genetic transformations were carried out employing the Agrobacterium-mediated approach (Fladung et al. 1997) using the Agrobacterium strain EHA105. WPM medium for the regeneration of transgenic plants was supplemented with $0.01 \%$ Pluronics F-68 (Sigma P-7061), thidiazuron $(0.01 \mu \mathrm{M})$ and antibiotics, cefotaxime $(500$ $\mathrm{mg} \mathrm{L}^{-1}$ ) for Agrobacteria elimination, and kanamycin $\left(50 \mathrm{mg} \mathrm{L}^{-1}\right)$ or hygromycin $(20 \mathrm{mg}$ $\mathrm{L}^{-1}$ ) for selection of transgenic shoots. Early flowering sterile plants (see below) were transferred to growth chambers (Weiss Technik) under the following culture conditions: light period: 16/8 (day/night), light intensity: $300 \mu \mathrm{E} \mathrm{m} \mathrm{m}^{-2} \mathrm{sec}^{-1}$, lamps: Phillips TLM 140W/33RS, relative humidity: $70 \%$, temperature: $22 / 19^{\circ} \mathrm{C}$. After a culture period of 6 18 months in the growth chambers transgenic plants were transferred to, and further grown in, a standard S1 greenhouse under natural daylight conditions.

\section{Induction of early flowering with gene-} tic transformation

Performance of early flowering poplar systems based on gene constructs (Fig. 1) 35S::LFY (Weigel \& Nilsson 1995), 35S::FT (Böhlenius et al. 2006), HSP::LFY (see below) and HSP::FT (Zhang et al. 2010) was evaluated. Both the $F T$ and $L F Y$ constructs containing Arabidopsis genes were kindly provided by O. Nilsson (Swedish University of Agricultural Sciences, Umeå, Sweden). HSP promoter is derived from the soybean heat-inducible promoter Hsp6871 (Schöffl et al. 1984). The HSP::LFY vector was constructed by DNA Cloning Service (Hamburg, Germany).

Cloning of gene constructs: (a) HSP::FT: HSP promoter was ligated to $F T$ cDNA, and was contained in the Gateway binary vector pK2GW7 (Karimi et al. 2002); (b) HSP:: $L F Y$ : $L F Y$ cDNA was ligated to binary vector p6-HSP-TP-OCS (DNA Cloning Service, Hamburg, Germany) after digestion with $B g l$ $I I$ and Xho I. Activation of flowering time genes was carried out in growth chambers with a heat treatment $\left(1 \mathrm{~h}, 40^{\circ} \mathrm{C}, 4-6\right.$ weeks $)$.

Induction of sterility using genetic transformation

Poplar was transformed with the PrMALE1

Tab. 1 - Sequence of primers used in this study (5'- $\left.3^{\prime}\right)$

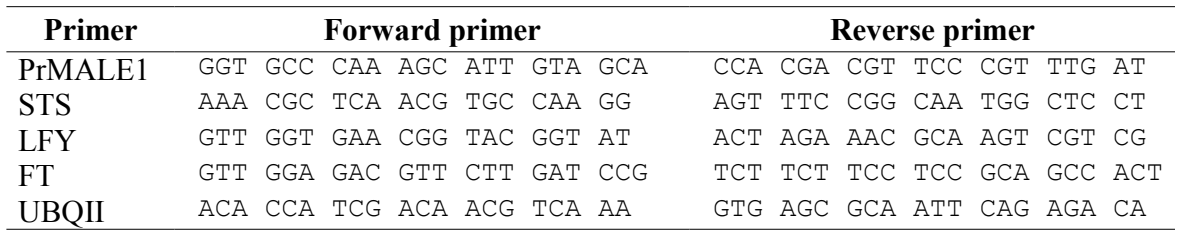
(Finnzymes, Espoo, Finland) with Oligo
::STS gene construct (Höfig et al. 2003), kindly provided by C. Walter (Forest Research Institute, Rotorua, New Zealand). Generation of transgenic lines containing $\mathrm{Pr}$ MALE1::STS and one early flowering gene construct (HSP::FT or $35 \mathrm{~S}:: F T$ ) was carried out using simultaneously two Agrobacterium strains, one containing the gene construct $\mathrm{Pr}$ MALE1::STS and the other one HSP::FT or $35 \mathrm{~S}:: F T$. Transgenic lines containing both gene constructs were selected using molecular analysis.

\section{$R N A$ extraction and reverse transcrip-} tion

Tissues (leaves, stems and roots) were collected and frozen in liquid $\mathrm{N}_{2}$ and stored at $-80^{\circ} \mathrm{C}$ until RNA extraction. Total RNA was isolated using the Plant RNA Isolation Mini Kit (Agilent, Wilmington, USA). Around 60 $\mathrm{mg}$ of liquid nitrogen frozen tissues were ground in Eppendorf tubes using metal balls and a Retsch mill (Retsch MM2, Germany). RNA was quantified using spectrophotometric OD260 measurements with a Nanodrop 1000 (Thermoscientific, Wilmington, USA) and RNA quality was assessed by OD260/ OD280 and OD260/OD230 ratios (both ratios were maintained between 1.8 and 2.1) and using the Agilent Bioanalyzer (Agilent Technologies Inc. Palo Alto, CA - RIN values $>6$ ). Contaminating DNA was removed from RNA samples using the Ambion turbo DNA-free (Ambion, Austin, TX, USA) according to the manufacturer's protocol. cDNA was synthesized with $30 \mathrm{ng} \mu \mathrm{l}^{-1}$ RNA using the DyNAmo cDNA Synthesis Kit $(\mathrm{dT})_{15}$ primers according to the manufacturer's instructions.

\section{Expression of STS gene in transgenic plants}

Expression of STS was studied using RTPCR. Gene UBQII was used as a reference gene. Primers (Tab. 1) were designed using Primer3Plus software (Rozen \& Skaletsky 2000) with melting temperatures around 60 ${ }^{\circ} \mathrm{C}$. PCR reactions were done in a $20 \mu \mathrm{l}$ volume containing $300 \mathrm{nM}$ of each primer, $2 \mu \mathrm{l}$ of cDNA sample ( $\sim 3.5 \mathrm{ng}$ of input RNA) and Maxima Hot Start Taq DNA Polymerase (Fermentas, St. Leon-Rot, Germany). RTPCR was performed using the following parameters: $10 \mathrm{~min}$. at $95^{\circ} \mathrm{C}$ and 40 cycles of $95^{\circ} \mathrm{C}$ for $30 \mathrm{sec}, 60^{\circ} \mathrm{C}$ for $1 \mathrm{~min}$ and $72{ }^{\circ} \mathrm{C}$ for $1 \mathrm{~min}$. 


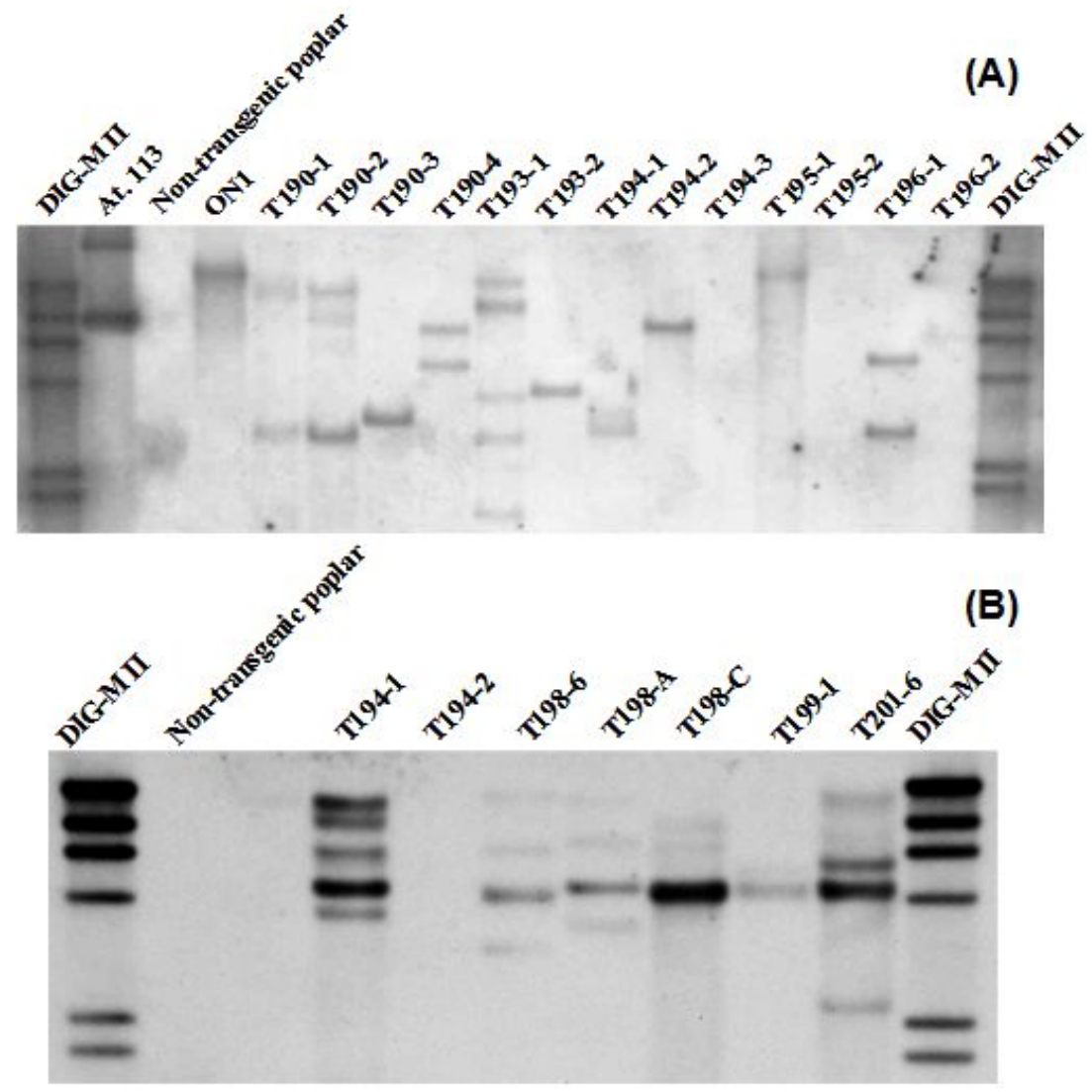

Extraction of DNA and molecular analysis

DNA extraction was followed by a standard protocol adapted from Doyle \& Doyle (1987), using 0.5-1.0 g leaf material and a modified extraction buffer [2\% alkyltrimethylammonium bromide (ATMAB), $0.1 \mathrm{M}$ Tris- $\mathrm{HCl}, 0.02 \mathrm{M}$ disodium-EDTA ( $\mathrm{pH} 8.0$ ), $1.4 \mathrm{M} \mathrm{NaCl}, 1 \%$ PVP]. Standard PCR techniques were used to detect and amplify transgenes. The PCR reaction used for all primers (Tab. 1) consisted of $94{ }^{\circ} \mathrm{C} / 2 \mathrm{~min}$, followed by 40 cycles $\left(94^{\circ} \mathrm{C} / 1 \mathrm{~min}, \mathrm{Ta} / 2\right.$ min, $72{ }^{\circ} \mathrm{C} / 2 \mathrm{~min}$ ) and finally $72{ }^{\circ} \mathrm{C} / 5$ min. Southern hybridisations were carried out with $20 \mu \mathrm{g}$ genomic DNA. DNA was digested enzymatically and separated using a $1.5 \%$ agarose gel and transferred onto a membrane by capillary transfer (Nylon membrane positively charged, Roche) in alkaline conditions. Prehybridization and hybridization were performed with the non-radiactive DIG (digoxigenine) system using DIGdUTP-labelled gene probes (Fladung \& Ahuja 1995). DIG probes were prepared with a PCR amplification Kit (PCR DIG Probe Synthesis Kit, Roche) using the different plasmids with the respective primer pairs. Probe hybridization and chemiluminescent reaction were performed according to Roche instructions with some modifications (Fladung \& Ahuja 1995).

Microscopic observation of anthers derived from transgenic plants

Anthers obtained form early flowering and early flowering-sterile plants were observed under an optical microscope to confirm presence or absence of pollen grains. Pollen germination tests were carried out with fresh
Fig. 2 - (A): Southern-blot analysis of DNA extracted from HSP::FT aspen leaves. Genomic DNA restriction with $S a c$ I. Twenty $\mu \mathrm{g}$ of genomic DNA from leaves were enzymatically digested, electrophorized in an agarose gel, blotted and subsequently detected using a digoxigenine-labelled $F T$ probe; (B): Southern-blot analysis of DNA extracted from PrMALE1::STS aspen leaves. Genomic DNA restriction with Hind III. Twenty $\mu \mathrm{g}$ of genomic DNA from leaves were enzymatically digested, electrophorated in an agarose gel, blotted and subsequently detected using a digoxigenine-labelled STS probe.

Tab. 2 - Genetic transformation of poplar with flowering time genes. $(* 1)$ : flowers with/lacking pollen grains can be found; (*2): normal ve getative growth until heat treatment; $(* 3)$ : flowers contain seldom pollen grains.

\begin{tabular}{|c|c|c|c|c|}
\hline \multirow{2}{*}{ Gene construct } & \multirow{2}{*}{ Poplar clone } & \multicolumn{2}{|c|}{ Flowering } & \multirow{2}{*}{ Vegetative growth } \\
\hline & & In vitro (Pollen) & Greenhouse (Pollen) & \\
\hline \multirow{2}{*}{$35 \mathrm{~S}:: L F Y$} & T89 & $+(-)$ & $+(+* 1)$ & dwarf \\
\hline & W52 & $+(-)$ & $+(+* 1)$ & dwarf \\
\hline \multirow{2}{*}{$\mathrm{HSP}:: L F Y$} & T89 & - & - & normal $* 2$ \\
\hline & W52 & - & - & normal $* 2$ \\
\hline \multirow{2}{*}{$35 \mathrm{~S}:: F T$} & T89 & $+(-)$ & - & normal \\
\hline & W52 & - & - & normal \\
\hline \multirow{2}{*}{ HSP::FT } & T89 & $+(-)$ & $+(* 3)$ & normal \\
\hline & W52 & $+(-)$ & $+(* 3)$ & normal \\
\hline
\end{tabular}

pollen using culture medium (Saccharose $10 \%$, Phytagel $\left.7.5 \mathrm{~g} \mathrm{~L}^{-1}\right)$. FDA test: microspore viability was estimated staining with fluorescein diacetate (Widholm 1972).

\section{Results}

Induction of early flowering in poplar with genetic transformation

Genetic transformation was performed with different gene constructs containing the $35 \mathrm{~S}$ or HSP promoter and the flowering time genes $L F Y$ or $F T$. We obtained five to ten transgenic lines with each gene construct. Transgenic lines obtained were analyzed with PCR and Southern-Blot analysis (Fig. 2). Single copy transgenic lines were selected for further studies.

35S:: $L F Y$ : early flowering lines where obtained with both poplar clones (T89 and 

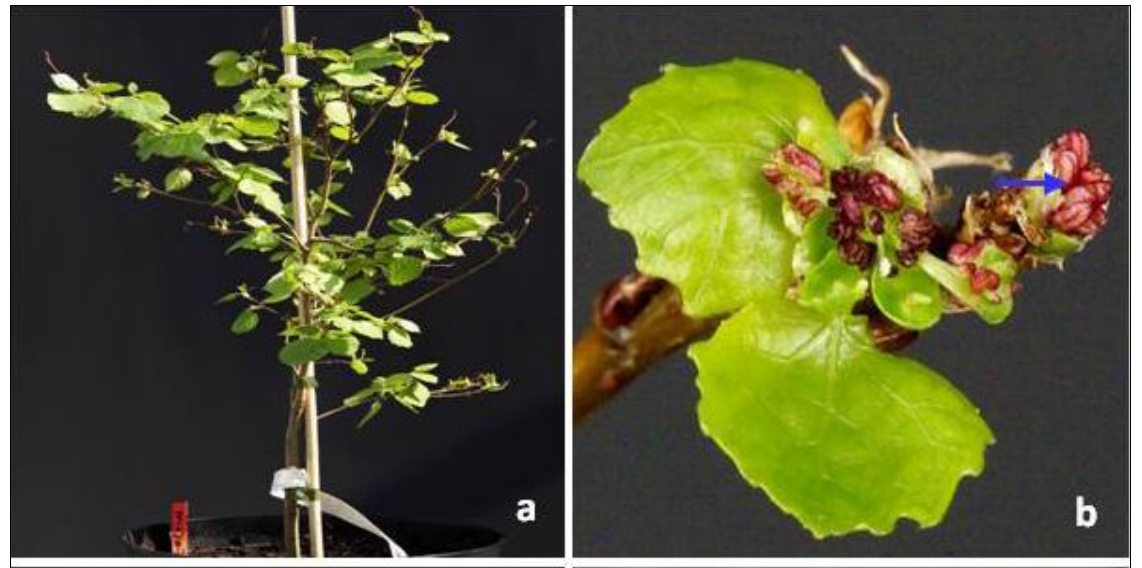

Fig. 3 - Flowering induction in poplar using genetic transformation with $L F Y$ gene. Arrow shows single flower. $35 \mathrm{~S}:: L F Y$ : dwarf vegetative growth (a), single flowers (b); HSP::LFY: normal vegetative growth (c), disturbed growth after heat treatment ( $1 \mathrm{~h}, 40^{\circ} \mathrm{C}, 4-6$ weeks). No flowers were obtained.
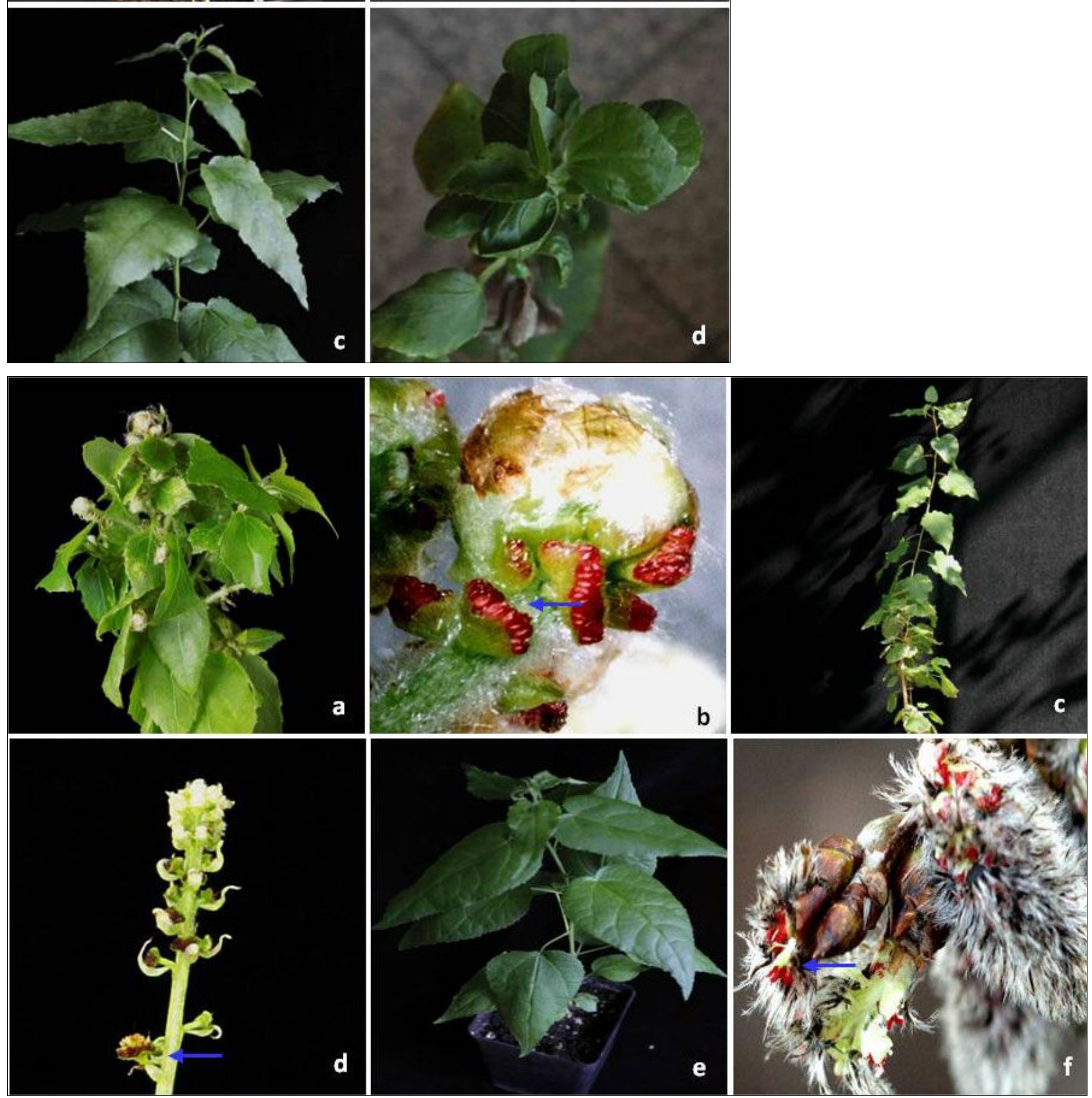

Fig. 4 - Flowering induction in poplar using genetic transformation with flowering time genes. Arrows show single flowers. 35S::FT: quite normal vegetative growth (a), catkin (b); HSP::FT: normal vegetative growth (c), catkin (d); non-transgenic T89 plants: vegetative growth (e), catkins (f). 

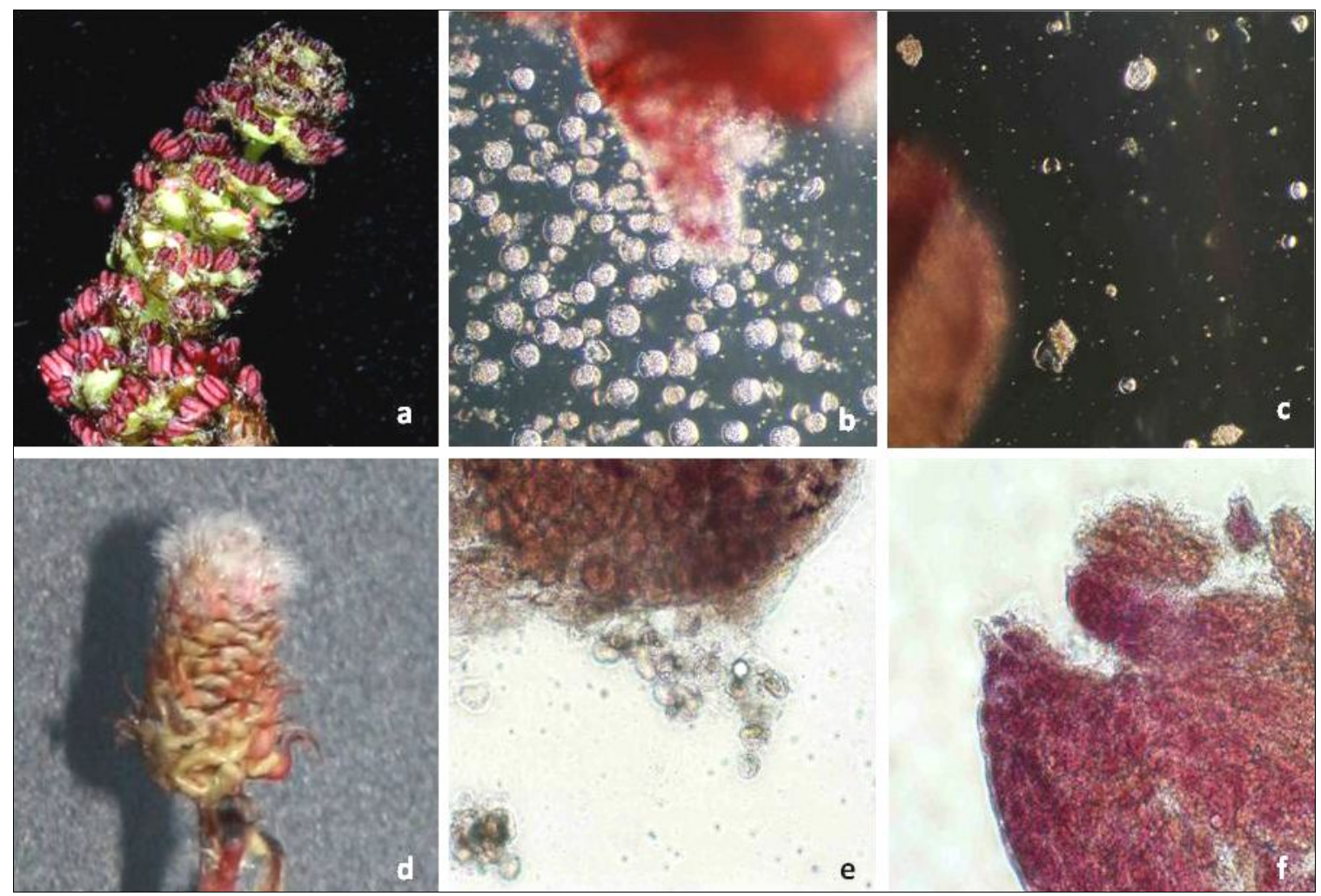

Fig. 5 - Catkin and anthers from early flowering heat-inducible poplar (a, b, c) and transgenic line T194-1 (d, e, f) transformed with the ste rility construct PrMALE1::STS. HSP ::FT: (a) catkin of HSP::FT plant; (b) anthers containing abundant pollen grains (seldom occurring event); (c): anthers containing low number of disturbed pollen grains. HSP::FT + PrMALE1::STS (Line T194-1): (d) abnormal catkin from early flowering transgenic line transformed with sterility gene construct PrMALE1::STS; (e): anther with sterile pollen grains; (f): anther devoid of pollen grains.
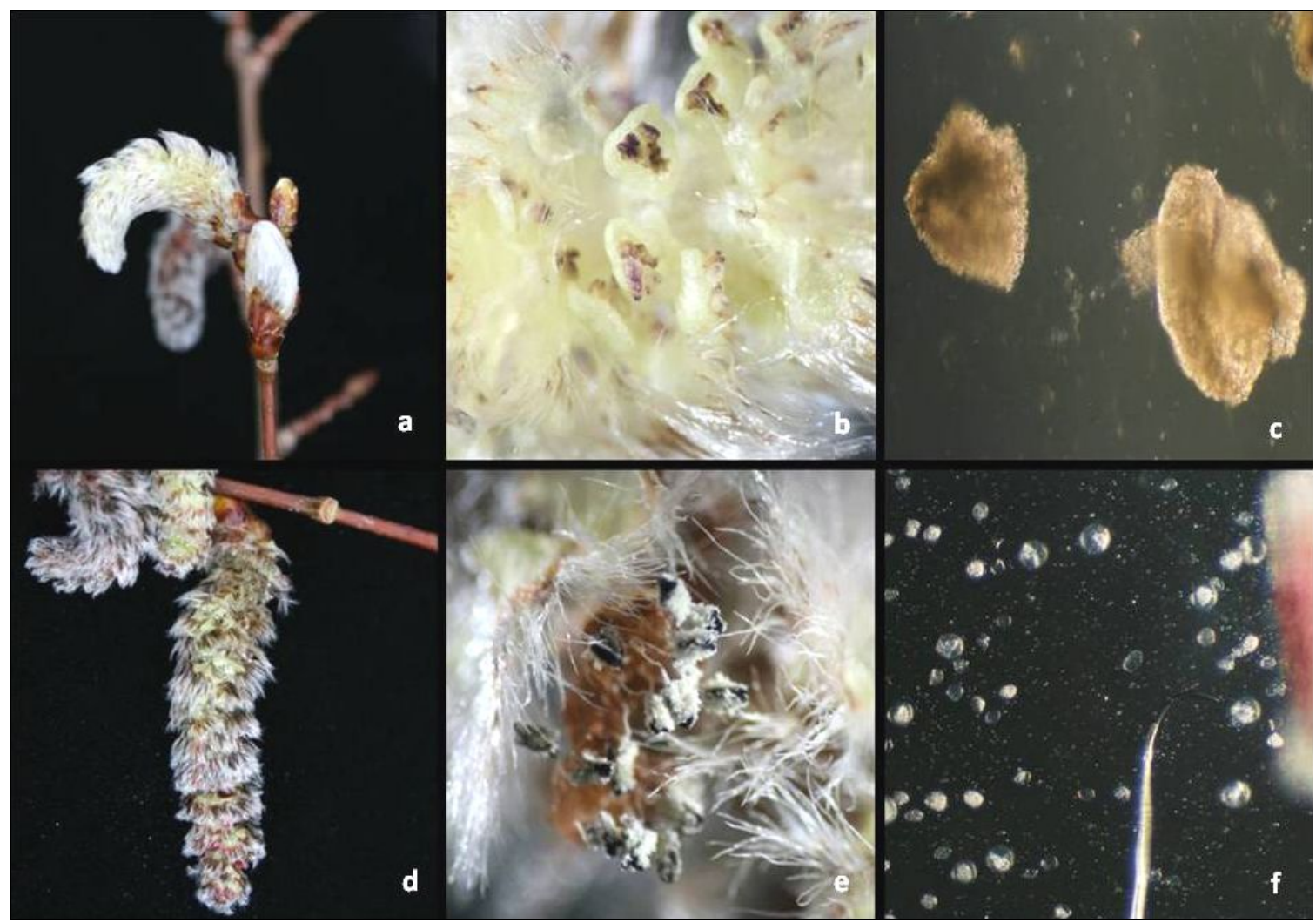

Fig. 6 - Genetic transformation of wildtype hybrid aspen clone T89 with PrMALE1::STS. (a): catkin type I (sterile); (b): disturbed anther growth; (c): anthers without pollen grains; (d): catkin type II (non-sterile); (e): anthers with pollen grains; (f): pollen grains. 
W52). This early flowering model (Weigel \& Nilsson 1995) was used for biosafety research before (Skinner et al. 2003, Hoenicka et al. 2006).

Incidence of sterility and disturbed plant growth reduces the utility of this model for biosafety research (Hoenicka et al. 2006). Early flowering occurs in spring and during the summer time. However, pollen grains were obtained only from greenhouse plants in spring. Furthermore, the presence of pollen in flowers was very variable, fluctuating yearly between $0 \%$ (only sterile flowers) to $100 \%$. Out of these results, we concluded that $L F Y$ effectively promotes flowering but not microsporogenesis.

HSP::LFY: The rationale behind promoter replacement, HSP instead of $35 \mathrm{~S}$ promoter, was the avoidance of dwarf plant growth caused by constitutive $L F Y$ expression. This approach allowed to obtain transgenic plants with a normal vegetative growth. However, heat-treatment disturbed plant growth (indicating $L F Y$ expression), and no flowering could be obtained (Fig. 3).

35S::FT: Only one transgenic line out of seven obtained in total showed early flowering under in vitro and growth chamber conditions. The flowers obtained under growth chamber conditions resembled strongly naturally developed poplar catkins (Fig. 4). However, early flowering was not stable and after one to two years no more flowers developed.

HSP::FT: The expression of the $F T$ gene regulated by the heat-inducible promoter allowed effective flowering induction and a normal looking plant phenotype. Early flowering lines where obtained with both poplar clones (T89 and W52). HSP::FT flowers are grouped in catkins resembling those from naturally grown poplar. However, there are still differences between naturally developed (wild) and HSP::FT poplar flowers (Fig. 4): no normal flower buds developed, catkin bracts were absent and microsporogenesis was not induced. Some few flowers, derived from summer heat-treated plants (Tab. 2), showed pollen grains the next spring (Fig. $5 \mathrm{c}-\mathrm{d}$ ). However, flowers obtained in the summer after the heat treatment lacked always pollen grains.

Evaluation of gene containment strategies in poplar

Transgenic lines were analyzed with PCR and Southern blot experiments (Fig. 2). Genetic transformation approach using the poplar wildtype strain W52 and combining two Agrobacterium strains, containing the $\mathrm{Pr}$ MALE1::STS and one early flowering gene construct (35S::FT or HSP::FT), produced many transgenic lines containing one single gene construct but only two lines containing both gene constructs, lines T198-A and T194-1 (Fig. 2). The line T198-A (PrMA-

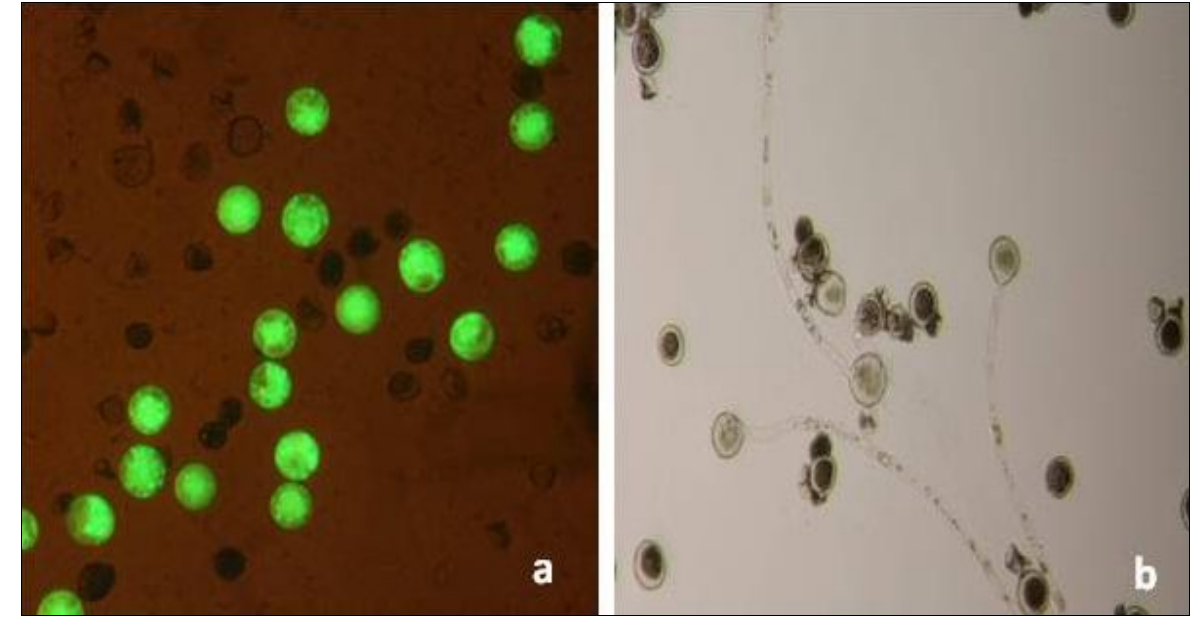

Fig. 7 - Viability tests of pollen grains from (catkins type II, line T199-1): (a) FDA test; (b) pollen germination tests.

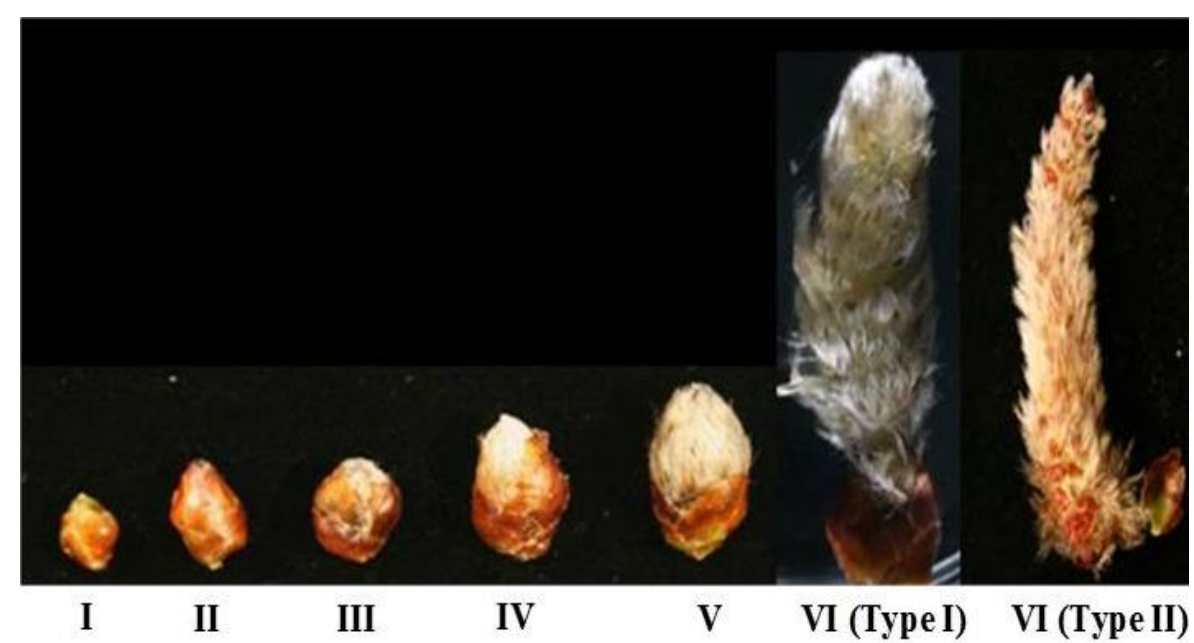

Fig. 8 - Catkin development in transgenic PrMALE1::STS hybrid aspen clone T89 (Line T199-1). Flower buds (I, II, III, IV, V), sterile (VI type I) and non-sterile (VI type II) catkins.

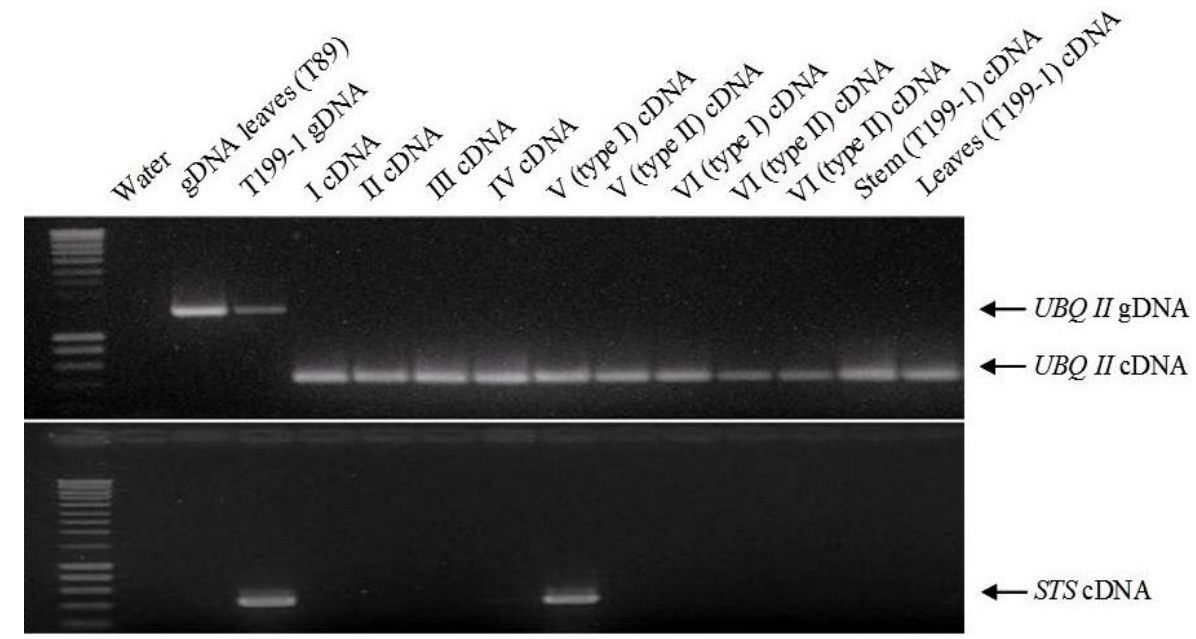

Fig. 9 - Stilbene synthese gene (STS) expression in flower buds and catkins at different developmental stages (see Fig. 8) of the PrMALE1::STS transgenic line T199-1. STS activity was detected in flower buds at the stage $\mathrm{V}$ (type I). UBQII gene was used as a control. 
Tab. 3 - Frequency of sterility in catkins from PrMALE1::STS transgenic hybrid aspen clone T89. (*): no pollen grains.

\begin{tabular}{lcccc}
\hline Catkins & $\begin{array}{c}\text { Catkins } \\
\text { with pollen }\end{array}$ & $\begin{array}{c}\text { in vitro } \\
\text { growth }\end{array}$ & FDA & Crossings \\
\hline Catkin type I & $0 / 15$ & $*$ & $*$ & $*$ \\
Catkin type II & $(0 \%)$ & + & + & + \\
Catkins obtained in total & $7 / 7$ & & & + \\
& $(100 \%)$ & + & + & + \\
\hline
\end{tabular}

LE1::STS/35S::FT) transformed with $35 \mathrm{~S}:: F T$ did not developed flowers under in vitro or greenhouse conditions. Similar results were obtained with single $35 \mathrm{~S}:: F T$ transgenic lines, as mentioned before. Transgenic line T194-1 (PrMALE1::STS/HSP:: FT) containing the HSP::FT produced catkins with disturbed development (Fig. 5). However, due to disturbed pollen development in HSP::FT poplar, no clear conclusions can be drawn regarding efficiency of the PrMALE1::STS sterility with the poplar wildtype strain W52 containing this early flowering system.

Genetic transformation of the non-transgenic hybrid aspen clone T89 allowed a more reliable evaluation of the sterility efficiency of PrMALE1::STS gene construct five years after genetic transformation. Transgenic line T199-1 contained the sterility gene construct PrMALE1::STS. Vegetative growth of $\mathrm{Pr}$ MALE1::STS transgenic plants resembled that of non-transgenic control plants. Development was disturbed in $68 \%$ of catkins (type I catkins), and those catkins were lacking pollen grains (Fig. 6, Tab. 3). However, pollen grains were obtained from some normal-looking catkins (type II catkins). The presence of viable pollen grains in catkins type II was confirmed with FDA tests, in vitro germination and crossings (Tab. 3, Fig. 7). Expression studies of STS gene were carried out in young catkins from transgenic plants (Fig. 9). The expression of STS was confirmed only in young catkins type I and not in type II, and no leaky expression was detected in leaves, stems or roots (Fig. 9). STS expression was weak in type I catkins at phase IV and stronger during phase V (Fig. 8 and Fig. 9). No STS expression was detected in mature type I catkins.

\section{Discussion}

\section{Early flowering in poplar}

The development of more efficient early flowering poplar systems would allow faster biosafety studies on genetic containment. Therefore, we evaluated different methods to induce early flowering in poplar. After some unsuccessful approaches using growth inhibitors like Paclobutrazol and Daminozide in the past (unpublished results), we focused on genetic transformation with flowering time genes for achieving this aim. The constitutive expression of the $L F Y$ gene (Weigel \& Nilsson 1995) allowed us initiating containment studies in poplar (Hoenicka et al. 2006). However, overexpression of $L F Y$ produces many side effects on vegetative growth and flower development, which can be detrimental for their broad use in biosafety research.

We tested a new approach, with the HSP trimental effect of $L F Y$ expression on flowering and plant growth. Our results showed that vegetative growth was significantly improved when $L F Y$ expression was under the control of the HSP promoter. However, activation of $L F Y$ through heat treatments (1h, $40^{\circ} \mathrm{C}$, 4-6 weeks), disturbed vegetative growth and no flowering was obtained. It is not clear why a short $L F Y$ activation still disturbs vegetative growth strongly and do not induce flowering. Short gene activation with the HSP promoter did not lead to an improvement of the $L F Y$ early flowering poplar model.

Early flowering systems based on the $F T$ gene from Arabidopsis, 35S::FT and HSP:: $F T$, were successful on flower induction. However, disturbed microsporogenesis is still a problem. The constitutive overexpression of FT promoted development of normal looking catkins during in vitro culture and growth chamber cultivation. However, no flowers were developed on $35 \mathrm{~S}:: F T$ transgenic poplar grown in the greenhouse (Tab. 2). Gene silencing of FT or some other flowering time genes may be avoiding long term flowering in $35 \mathrm{~S}:: F T$ system. The HSP::FT gene construct allowed a much more reliable flower induction compared to $35 \mathrm{~S}:: F T$. However, pollen grains were obtained very seldom, and only during spring in summer heat-treated greenhouse plants (Tab. 2).

Several approaches have been successful of early induction of completely fertile flowers in woody plants. The constitutive expression of CiFT (the citrus FT homologue) in Trifoliate orange (Poncirus trifoliata L. - Endo et al. 2005), $L F Y$ or $A P 1$ in Carrizo citrange (Citrus sinensis L. Osbeck $\times$ Poncirus trifoliata L. Raf. - Peña et al. 2001) and Bppromoter, expecting an effective and less de-
MADS4 from birch (Elo et al. 2007) in apple (Malus domestica Borkh. - Flachowsky et al. 2007) induced early formation of fertile flowers. However, phenotype induced by introduced flowering time genes is very variable depending of the plant species. For instance, the BpMADS4 gene construct from birch was also transferred to poplar; instead of early flower formation a retarded senescence was observed in resulting transgenic lines (Hoenicka et al. 2008). Thus, it is not clear why the transformation with a single gene can promote the development of flowers and pollen grains in some plant species but not in others.

Hitherto available transgenic early flowering poplar models show many drawbacks when used as standard tool in biosafety research. Disturbed microsporogenesis is still the main problem detected in those models. Research aiming improvement of early flowering may provide a more efficient tool for this aim in the next future. Use of natural early flowering clones, as it has been reported for poplar (Meilan et al. 2004), may represent a reliable alternative for such studies. Our results showed that the hybrid aspen T89 represent an appropriate choice for such studies as flowers were obtained four to five years after genetic transformation; Populus tremula L. clones begin flowering usually after a vegetative phase of seven to ten years. However, development of faster flowering systems would facilitate application on biosafety studies. The improvement of early flowering system based on genetic transformation can be carried out with some other flowering genes (single gene approach) or following a co-transformation strategy with flowering genes (gene stacking approach).

\section{Evaluation of gene containment strate- gies in poplar}

Biosafety studies were initiated in our group with the first available early flowering model, 35S::LFY (Weigel \& Nilsson 1995). In a former publication, we showed with this model that genetic transformation with CGPDHC::Vst1 promoted sterility in poplar (Hoenicka et al. 2006). However, the weak performance of $35 \mathrm{~S}:: L F Y$ was a strong burden for generation and maintenance of double transgenic lines with other sterility constructs, e.g., TA29::Barnase (unpublished results). Those transgenic lines showed a very weak performance, and could not be grown under greenhouse conditions. We suppose that leaky Barnase expression, due to unspecific TA29 promoter activity ( $\mathrm{Li}$ et al. 2007), has represented a strong burden for $35 \mathrm{~S}:$ : $L F Y$ poplar.

Important progress has been reached on flowering time regulation in plants (reviewed in Turnbull 2011). Consequently, we incorporated new early flowering models into our research. Two gene constructs based on the 
$F T$ gene, HSP::FT and 35S::FT, were used for early flowering induction. The vegetative growth and flower development of double transgenic lines (T194-1 and T198-A) was significantly improved with both models. However, both systems do not represent a good option for biosafety studies, due to disturbed pollen development.

In the frame of our biosafety work, a field release was also planed. Therefore, transgenic lines were also generated with normal flowering poplar W52 (non-transgenic). Some genetic transformations were also carried out with hybrid aspen clone T89. Resulting transgenic lines were maintained in the greenhouse for many years. However, no field release could be carried out, due to the increasing legal restrictions toward GMOs in Germany. After four years in the greenhouse, we detected first flowers in hybrid aspen clone T89 containing the MALE1::STS sterility construct (transgenic line T199-1). This result was surprising, because other poplar clones used in our institute flower only after seven to ten years.

Hybrid aspen clone T89 allowed us a first approach for evaluation of the MALE1::STS sterility construct under controlled conditions. STS-induced male sterility using the gymnosperm promoter PrMALE1 was demonstrated in tobacco before (Höfig et al. 2003). STS inhibits flavonol biosynthesis in the tapetum, leading to a disturbed pollen development. The number of pollen grains was reduced and a very low pollen germination was reported in 2/10 transgenic lines (Höfig et al. 2003). In hybrid aspen, pollen development was disturbed in $68 \%$ of catkins. We confirmed specific activity of $\mathrm{Pr}$ MALE1 in catkins (Fig. 9). However, a low activity of this promoter in some cells, due to variable gene expression level, may be a possible reason for presence of viable pollen grains in some catkins. Epigenetic modifications may result in a mosaic gene expression (Bastar et al. 2004, Robbins et al. 2009, Freeman et al. 2011). T-DNA positional effects may be playing an important role too (Kumar \& Fladung 2001). These results were derived from nine ramets derived from the same transgenic lines. A higher number of transgenic lines would possible allow obtaining lines showing a more efficient sterility induction.

\section{Acknowledgements}

This work was supported by the German Ministry of Education and Research (Biosafety Research; project number $0315210 \mathrm{C}$ ). We thank C. Walter (Forest Research Institute, Rotorua, New Zealand) and O. Nilsson (University Umeå, Sweden) for kindly providing gene constructs, D. Ebbinghaus and A. Schellhorn, for helpful technical assistance in the lab, and greenhouse staff (M. Hunger, G. Wiemann, R. Ebbinghaus, M. Spauszus) for plant cultivation. This work has been presented at the "First Biosafety Workshop" of COST Action FP0905 held in Hamburg (Germany) on September 9 ${ }^{\text {th }}, 2010$.

\section{References}

Bastar MT, Luthar Z, Skof S, Bohanec B (2004). Quantitative determination of mosaic GFP gene expression in tobacco. Plant Cell Reports 22 (12): 939-944. - doi: 10.1007/s00299-004-07822

Blázquez MA, Weigel D (1999). Independent regulation of flowering by phytochrome $\mathrm{B}$ and gibberellins in Arabidopsis. Plant Physiology 120 (4): 1025-1032. - doi: 10.1104/pp.120.4. 1025

Böhlenius H, Huang T, Charbonnel-Campaa L, Brunner AM, Jansson S, Strauss SH, Nilsson O (2006). CO/FT regulatory module controls timing of flowering and seasonal growth cessation in trees. Science 312:1040-1043. - doi: 10.1126/ science. 1126038

Brunner AM, Mohamed R, Meilan R, Sheppard LA, Rottman WH, Strauss S (1998). Genetic engineering of sexual sterility in shade trees. Journal of Arboriculture 24: 263-271. [online] URL: http://www.cfeaguisamo.org/webcfea/images/documentos/documentacion tecnica/arboricultura/ REVISTAS/ARBORICULTURE AND URBAN FORESTRY/1998/SEPTEMBER/4.pdf

Doyle JJ, Doyle JL (1987). A rapid DNA isolation procedure for small quantities of fresh leaf tissue. Phytochemical Bulletin 19: 11-15.

Elo A, Lemmetyinen J, Turunen ML, Tikka L, Sopanen T (2001). Three MADS-box genes similar to APETALA1 and FRUITFULL from silver birch (Betula pendula). Physiologia Plantarum 112 (1): 95-103. - doi: 10.1034/j.1399-3054. 2001. 1120113.x

Elo A, Lemmetyinen J, Novak A, Keinonen K, Porali I, Hassinen M, Sopanen T (2007). BpMAD$\mathrm{S} 4$ has a central role in inflorescence initiation in silver birch (Betula pendula). Physiologia Plantarum 131 (1): 149-158. - doi: 10.1111/ppl.2007. 131.issue-1

Endo T, Shimada T, Fujii H, Kobayashi Y, Araki T, Omura M (2005). Ectopic expression of an FT homolog from citrus confers an early flowering phenotype on trifoliate orange (Poncirus trifoliata L. Raf.). Transgenic Research 14 (5): 703712. - doi: 10.1007/s11248-005-6632-3

Fischer R, Budde I, Hain R (1997). Stilbene synthase gene expression causes changes in flower colour and male sterility in tobacco. The Plant Journal 11 (3): 489-498. - doi: 10.1046/j.1365313X.1997.11030489.x

Fladung M, Ahuja M (1995). Sandwich method for non-radioactive hybridisations. BioTechniques 18 (5): 800-802.

Fladung M, Hoenicka H (2004). Erzeugung transgener steriler Zitterpappeln zur Verhinderung eines vertikalen Gentransfers in forstliche Oekosysteme. Gesunde Pflanzen 56: 195-200. - doi: 10.1007/s10343-004-0044-9

Fladung M, Kumar S, Ahuja MR (1997). Genetic transformation of Populus genotypes with different chimeric gene constructs: Transformation ef- ficiency and molecular analysis. Transgenic Research 6: 111-121. - doi 10.1023/A:101842 1620040

Flachowsky H, Peil A, Sopanen T, Elo A, Hanke V (2007). Overexpression of BpMADS4 from silver birch (Betula pendula) in apple (Malus $x$ domestica) induces early flowering. Plant Breeding 126: 137-145. - doi: 10.1111/j.1439-0523.2007. 01344.x

Flachowsky H, Le Roux PM, Peil A, Patocchi A, Richter K, Hanke MV (2011). Application of a high-speed breeding technology to apple (Malus domestica) based on transgenic early flowering plants and marker-assisted selection. New Phytologist 192 (2): 364-377. - doi: 10.1111/nph 2011.192.issue- 2

Freeman J, Sparks CA, West J, Shewry PR, Jones HD (2011). Temporal and spatial control of transgene expression using a heat-inducible promoter in transgenic wheat. Plant Biotechnology Journal 9 (7): 788-796. - doi: 10.1111/pbi. 2011.9.issue-7

Gan Y, Fan Y, Yang Y, Dai B, Gao D, Wang X, Wang K, Yao M, Wen H, Yu W (2010). Ectopic expression of MNX gene from Arabidopsis thaliana involved in auxin biosynthesis confers male sterility in transgenic cotton (Gossypium hirsutum L.) plants. Molecular Breeding 26 (1): 77-89. - doi: 10.1007/s11032-009-9378-4

García-Sogo B, Pineda B, Castelblanque L, Antón T, Medina M, Roque E, Torresi C, Beltrán JP, Moreno V, Cañas LA (2010). Efficient transformation of Kalanchoe blossfeldiana and production of male-sterile plants by engineered anther ablation. Plant Cell Reports 29 (1): 61-77. - doi: 10.1007/s00299-009-0798-8

Hoenicka H, Fladung M (2006). Biosafety in Populus spp. and other forest trees: from non-native species to taxa derived from traditional breeding and genetic engineering. Trees 20: 131-144. doi: 10.1007/s00468-005-0023-5

Hoenicka H, Nowitzki O, Hanelt D, Fladung M (2008). Heterologous overexpression of the birch FRUITFULL-like MADS-box gene BpMADS4 prevents normal senescence and winter dormancy in Populus tremula L. Planta 227 (5): 10011011. - doi: 10.1007/s00425-007-0674-0

Hoenicka H, Nowitzki O, Debener T, Fladung M (2006). Faster evaluation of induced floral sterility in transgenic early flowering poplar. Silvae Genetica 55 (6): 285-291. [online] URL: http://allgemeineforstundjagdzeitung.com/filead$\mathrm{min} /$ content/dokument/archiv/silvaegenetica/55 2006/55-6-285.pdf

Höfig KP, Moyle RL, Putterill J, Walter C (2003). Expression analysis of four Pinus radiata male cone promoters in the heterologous host Arabidopsis. Planta 217 (6): 858-867. - doi: 10.1007/s00425-003-1057-9

Höfig KP, Moller R, Donaldson L, Putterill J, Walter C (2006). Towards male sterility in Pinus radiata - a stilbene synthase approach to genetically engineer nuclear male sterility. Plant Biotechnology Journal 4 (3): 333-343. - doi: 10.1111/pbi.2006.4.issue-3

Hsu CY, Liu Y, Luthe DS, Yuceer C (2006). Po- 
plar FT2 shortens the juvenile phase and promotes seasonal flowering. Plant Cell 18 (8): 18461861. - doi: 10.1105/tpc.106.041038

Karimi M, Inzé D, Depicker A (2002). GATEWAYTM vectors for Agrobacterium-mediated plant transformation. Trends in Plant Science 7 (5): 193-195. - doi: 10.1016/S1360-1385(02) 02251-3

Koltunow AM, Truettner J, Cox KH, Wallroth M, Goldberg RB (1990). Different temporal and spatial gene expression patterns occur during anther development. Plant Cell 2 (12): 1201-1224. - doi: 10.1105/tpc.2.12.1201

Kumar S, Fladung M (2001). Gene stability in transgenic aspen (Populus). II. Molecular characterization of variable expression of transgene in wild and hybrid aspen. Planta 213: 731-740. doi: $10.1007 / \mathrm{s} 004250100535$

Lemmetyinen J, Keinonen K, Sopanen T (2004). Prevention of the flowering of a tree, silver birch. Molecular Breeding 13 (3): 243-249. - doi: 10.1023/B:MOLB.0000022525.96200.53

Li J, Brunner AM, Shevchenko O, Meilan R, Ma C, Skinner JS, Strauss SH (2007). Efficient and stable transgene suppression via RNAi in fieldgrown poplars. Transgenic Res 17 (4): 679-694. [online] URL: http:/www.ncbi.nlm.nih.gov /pubmed/17929189

Liu C, Thong Z, Yu H (2009). Coming into bloom: the specification of floral meristems. Development 136 (20): 3379-3391. - doi: 10.1242/ dev.033076

Lloyd G, McCown B (1980). Commercially-feasible micropropagation of mountain laurel, $\mathrm{Kal}$ mia latifolia, by use of shoot-tip culture. Combined Proceedings, International Plant Propagators' Society, vol. 30, pp. 421-427.

Mariani C, Beuckeleer MD, Truettner J, Leemans J, Goldberg RB (1990). Induction of male sterility in plants by a chimaeric ribonuclease gene. Nature 347: 737-741. - doi: 10.1038/347737a0

Meilan R (1997). Floral induction in woody angiosperms. New Forests 14:179-202. - doi: 10.1023/A:1006560603966

Meilan R, Brunner, Skinner J, Strauss S (2001) Modification of flowering in transgenic trees, In "Molecular breeding of woody plants" (Komamine A, Morohoshi N eds). Elsevier Science BV, Amsterdam, The Netherlands, pp. 247-256.

Meilan R, Sabatti M, Ma C, Kuzminsky E (2004). An early-flowering genotype of Populus. Journal of Plant Biology 47 (1): 52-56. - doi: 10.1007/ BF03030228

Mouradov A, Sawbridge T, Hamdorf B, Glassick

T, Murphy L, Marla S, Yang Y, Teasdale RD
(1998). Genetic engineering of reproductive sterility in Pinus radiata. Acta Horticulturae 461: 417-423.

Nawaz-ul-Rehman MS, Mansoor S, Khan AA, Zafar Y, Briddon RW (2007). RNAi-mediated male sterility of tobacco by silencing TA29. Molecular Biotechnology 36 (2): 159-165. - doi: 10.1007/ s12033-007-0025-1

Nizampatnam NR, Doodhi H, Kalinati Narasimhan Y, Mulpuri S, Viswanathaswamy DK (2009). Expression of sunflower cytoplasmic male sterility-associated open reading frame, orfH522 induces male sterility in transgenic tobacco plants. Planta 229 (4): 987-1001. - doi: 10.1007/s00425-009-0888-4

Paddon CJ, Hartley RW (1986). Cloning, sequencing and transcription of an inactivated copy of Bacillus amyloliquefaciens extracellular ribonuclease (barnase). Gene 40 (2-3): 231-239. - doi: 10.1016/0378-1119(85)90045-9

Palmiter RD, Behringer RR, Quaife CJ, Maxwell F, Maxwell IH, Brinster RL (1987). Cell lineage ablation in transgenic mice by cell-specific expression of a toxin gene. Cell 50: 435-443. - doi: 10.1016/0092-8674(87)90497-1

Peña L, Martín-Trillo M, Juárez J, Pina JA, Navarro L, Martínez-Zapater JM (2001). Constitutive expression of Arabidopsis LEAFY or APETALA1 genes in citrus reduces their generation time. Nature Biotechol. 19: 263-267. - doi: 10.1038/85719

Robbins ML, Wang P, Sekhon RS, Chopra S (2009). Gene structure induced epigenetic modifications of pericarp color1 alleles of maize result in tissue-specific mosaicism. PLoS ONE 4 (12): e8231. - doi: 10.1371/journal.pone.00082 31

Rottmann WH, Meilan R, Sheppard LA, Brunner AM, Skinner JS, Ma C, Cheng S, Jouanin L, Pilate G, Strauss SH (2000). Diverse effects of overexpression of LEAFY and PTLF, a poplar (Populus) homolog of LEAFY/FLORICAULA, in transgenic poplar and Arabidopsis. The Plant Journal 22 (3): 235-245. - doi: 10.1046/j.1365313x.2000.00734.x

Rozen S, Skaletsky HJ (2000). Primer3 on the WWW for general users and for biologist programmers. In: "Bioinformatics methods and protocols: methods in molecular biology" (Krawetz S, Misener S eds). Humana Press, Totowa, NJ, USA, pp. 365-386.

Schöffl F, Raschke E, Nagao RT (1984). The DNA sequence analysis of soybean heat-shock genes and identification of possible regulatory promoter elements. EMBO Journal 3 (11): 2491-2497. [online] URL: http:/www.ncbi.nlm.nih.gov/ pmc/articles/PMC557717/pdf/emboj003150049.pdf

Schultz EA, Haughn GW (1991). LEAFY, a homeotic gene that regulates inflorescence development in Arabidopsis. Plant Cell 3 (8): 771-781. doi: 10.1105/tpc.3.8.771

Skinner JS, Meilan R, Ma C, Strauss S (2003). The Populus PTD promoter imparts floral-predominant expression and enables high levels of floral-organ ablation in Populus, Nicotiana and Arabidopsis. Molecular Breeding 12:119-132. doi: 10.1023/A:1026044927910

Strauss SH, Rottmann WH, Brunner AM, Sheppard LA (1995). Genetic engineering of reproductive sterility in forest trees. Molecular Breeding 1 (1): 5-26. - doi: 10.1007/BF01682086 Tränkner C, Lehmann S, Hoenicka H, Hanke MV, Fladung M, Lenhardt D, Dunemann F, Gau A, Schlangen K, Malnoy M, Flachowsky H (2010). Over-expression of an FT-homologous gene of apple induces early flowering in annual and perennial plants. Planta 232: 1309-1324. - doi: 10.1007/s00425-010-1254-2

Turnbull C (2011). Long-distance regulation of flowering time. Journal of Experimental Botany 62 (13): 4399-4413. - doi: 10.1093/jxb/err191

Wada M, Cao QF, Kotoda N, Soejima J, Masuda T (2002). Apple has two orthologues of FLORICAULA/LEAFY involved in flowering. Plant Molecular Biology 49 (6): 567-77. - doi: 10.1023/A:1015544207121

Wei H, Meilan R, Brunner AM, Skinner JS, Ma C, Gandhi HT, Strauss SH (2006). Field trial detects incomplete barstar attenuation of vegetative cytotoxicity in Populus trees containing a poplar LEAFY promoter::barnase sterility transgene. Molecular Breeding 19 (1): 69-85. - doi: 10.1007/s11032-006-9045-y

Weigel D, Nilsson O (1995). A developmental switch sufficient for flower initiation in diverse plants. Nature 377: 95-500. - doi: 10.1038/ $377495 \mathrm{a} 0$

Widholm JM (1972). The use of fluorescein diacetate and phenosafranine for determining viability of cultured plant cells. Biotechnic and $\mathrm{Hi}$ stochemistry 47 (4): 189-194. - doi: 10.3109/ 10520297209116483

Zhang H, Harry DE, Ma C, Yuceer C, Hsu CY, Vikram V, Shevchenko O, Etherington E, Strauss SH (2010). Precocious flowering in trees: the FLOWERING LOCUS T gene as a research and breeding tool in Populus. Journal of Experimental Botany 61 (10): 2549-2560. - doi: 10.1093/jxb/erq092 